\title{
Reference ranges for TSH and thyroid hormones
}

Krzysztof Lewandowski, $\stackrel{\text { Aff1 }}{\text { Cow }}$

Corresponding Affiliation: Aff1

\begin{tabular}{|l|l|l||l||}
\hline \hline \multicolumn{2}{|l||}{ ArticleInfo } \\
\hline \hline ArticleID & $:$ & 205 \\
\hline \hline ArticleDOI & $:$ & $10.1186 / 1756-6614-8-S 1-A 17$ \\
\hline \hline ArticleCitationID & $:$ & A17 \\
\hline \hline ArticleSequenceNumber & $:$ & 17 \\
\hline \hline ArticleCategory & $:$ & Meeting abstract \\
\hline \hline ArticleFirstPage & $:$ & 1 \\
\hline \hline ArticleLastPage & $:$ & 3 \\
\hline \hline ArticleHistory & $:$ & $\begin{array}{l}\text { RegistrationDate } \\
\text { OnlineDate }\end{array}$ \\
\hline \hline & & $\begin{array}{l}\text { Lewandowski; licensee BioMed Central Ltd.2015 } \\
\text { This article is published under license to BioMed Central } \\
\text { Ltd. This is an Open Access article distributed under the } \\
\text { terms of the Creative Commons Attribution License } \\
\text { http://creativecommons.org/licenses/by/4.0), which permits }\end{array}$ \\
\hline ArticleCopyright & $:$ & $\begin{array}{l}\text { unrestricted use, distribution, and reproduction in any } \\
\text { medium, provided the original work is properly cited. The } \\
\text { Creative Commons Public Domain Dedication waiver } \\
\text { http://creativecommons.org/publicdomain/zero/1.0/) applies } \\
\text { to the data made available in this article, unless otherwise } \\
\text { stated. }\end{array}$ \\
\hline \hline
\end{tabular}

\section{Aff1}

Department of Endocrinology and Metabolic Diseases, Polish Mother's Memorial Research Institute, The Medical University of Lodz, Lodz, Poland

Spring School of Thyroidology organized by the Polish Thyroid Association 2014: abstracts of invited lectures

Spring School of Thyroidology organized by the Polish Thyroid Association 2014

Miedzyzdroje, Poland

23-24 May 2014

Publication of this supplement was funded by the Polish Thyroid Association. The Supplement Editors declare that they have no competing interests.

Meeting abstracts

Andrzej Lewinski

Mariusz Stasiolek 
Though TSH remains the most commonly used endocrine test in clinical practice, the issue of an appropriate TSH, and to a lesser extent, free T4 and free T3 reference ranges is still under debate. First of all the distribution of TSH reference range is not normal, with median values (also depending on population iodine intake) usually between 1-1.5 $\mathrm{mU} / \mathrm{L}[\underline{1}-\underline{3}]$. On the other hand, upper TSH reference limit is (assay-dependent) usually around 4.2-4.5 $\mathrm{mU} / \mathrm{L}$. There is also an argument that significant number of patients (up to 30\%) with TSH above $3.0 \mathrm{mU} / \mathrm{L}$ have an occult autoimmune thyroid disease [4]. On the other hand the upper normal TSH reference range in elderly subjects (i.e. 70 plus years) may extend up to around $6.0 \mathrm{mU} / \mathrm{L}$, with relative small changes in free hormones. This phenomenon also applies to elderly patients, where autoimmune thyroid disease had been ruled out [ $\underline{1}, \underline{2}]$. Furthermore, there is little evidence of any adverse effects of autoimmune thyroid disease in the elderly in the absence of an overt hypothyroidism. Indeed, Wang et al [ 5 ] surprisingly demonstrated decreased frailty in elderly subjects with raised titres of thyroid autoantibodies. It is also well known that in the setting of subclinical hypothyroidism, concentrations of free T4 start to decline below $10 \mathrm{pmol} / \mathrm{L}$ only with TSH above 6-7 mU/L in elderly subjects, though a decline in free T4 is more pronounced in the young (particularly in those aged 20-29 years), where free T4 starts to decline for TSH concentrations above $4.5 \mathrm{mU} / 1$ [ 6 ]. Another issue pertains to the risk of cardiovascular disease in subjects with subclinical hypothyroidism. There are data from post-menopausal women enrolled into the Women Health Initiative study, where an increase in the risk of myocardial infarction was demonstrated only for TSH concentrations above $7.0 \mathrm{mU} / \mathrm{L}$ []].

A separate issue, extensively discussed elsewhere []], pertains to alterations of TSH and free thyroid hormones during pregnancy. In particular there is decrease in TSH in the first trimester followed by a gradual return to pre-pregnancy values. In contrast, there is an increase in free T4 in the first trimester, while in the third trimester free T4 concentrations are usually at the lower end of the standard (i.e. pre-pregnancy) reference range, or even just below the lower reference limit. Hence, there is an urgent need (postulated in the Endocrine Society Guidelines []]) to create separate reference ranges for TSH and free thyroid hormones during pregnancy, possible with reference to each trimester. There are also recent data from China [9], where the authors demonstrated that the above-mentioned first trimester-related alterations in TSH and free T4, become only really visible after about $5^{\text {th }}-6^{\text {th }}$ week of gestation. The authors of this study suggest that standard reference ranges for TSH and free T4 can be applied up to this point of gestation.

\section{References}

1. Fontes R, Coeli CR, Aguiar F, Vaisman M: Reference interval of thyroid stimulating hormone and free thyroxine in a reference population over 60 years old and in very old subjects (over 80 years): comparison to young subjects. Thyroid Res 2013,6(1):13. 10.1186/1756-6614-6-13

2. Vadiveloo T, Donnan PT, Murphy MJ, Leese GP: Age- and Gender-Specific TSH Reference Intervals in People With No Obvious Thyroid Disease in Tayside, Scotland: The Thyroid Epidemiology, Audit, and Research Study (TEARS). J Clin Endocrinol Metab 2013,98(3):1147-1153. 10.1210/jc.2012-3191

3. Biondi B: The Normal TSH Reference Range: What Has Changed in the Last Decade? J Clin Endocrinol Metab 2013,98(9):3584-3587. 10.1210/jc.2013-2760

4. Spencer CA, Hollowell JG, Kazarosyan M, Braverman LE: National Health and Nutrition Examination Survey III: Thyroid-Stimulating Hormone (TSH)-Thyroperoxidase Antibody Relationships Demonstrate That TSH Upper Reference Limits May Be Skewed by Occult Thyroid Dysfunction. J Clin Endocrinol Metab 2007,92(11):4236-4240. 10.1210/jc.2007-0287

5. Wang GC, Talor MV, Rose NR, Cappola AR, Chiou RB, Weiss C, et al:: Thyroid autoantibodies are associated with a reduced prevalence of frailty in community-dwelling older women. $J$ Clin Endocrinol Metab 2010,95(3):1161-1168. 10.1210/jc.2009-1991

6. Hadlow NC, Rothacker KM, Wardrop R, Brown SJ, Lim EM, Walsh JP: The Relationship Between TSH and Free T4 in a Large Population Is Complex and Nonlinear and Differs by Age and Sex. J Clin Endocrinol Metab 2013,98(7):2936-2943. 10.1210/jc.2012-4223 
7. LeGrys VA, Funk MJ, Lorenz CE, Giri A, Jackson RD, Manson JE, Schectman R, Edwards TL, Heiss G, Hartmann KE: Subclinical Hypothyroidism and Risk for Incident Myocardial Infarction Among Postmenopausal Women. J Clin Endocrinol Metab 2013,98(6):2308-2317. 10.1210/jc.2012-4065

8. De Groot L, Abalovich M, Alexander EK, Amino N, Barbour L, Cobin RH, et al:: Management of Thyroid Dysfunction during Pregnancy and Postpartum: An Endocrine Society Clinical Practice Guideline. $J$ Clin Endocrinol Metab 2012,97(8):2543-2565. 10.1210/jc.2011-2803

9. Li C, Shan Z, Mao J, Wang W, Xie X, Zhou W, et al.: Assessment of Thyroid Function During FirstTrimester Pregnancy: What Is the Rational Upper Limit of Serum TSH During the First Trimester in Chinese Pregnant Women? J Clin Endocrinol Metab 2014,99(1):73-79. 10.1210/jc.2013-1674 